\title{
Pessoa em devir: a escrita no grande tempo, o sujeito num múltiplo e único espaço
}

\author{
Moisés Carlos de Amorim ${ }^{1}$ \\ Diego Pinto de Sousa ${ }^{2}$
}

\section{Resumo}

O fenômeno da heteronímia encontrou como origeme fonte mais profícua aescrita polifônica do poetaFernando Pessoa.Emsua obra, testifica-se uma complexa e dinâmica relação espaço/tempo da criação literária, havendo uma confluência de múltiplas temporalidades, facetas e personalidades num dialógico espaço artístico-biográfico. Nesta reflexão identificamos em conceitos bakhtinianos, o cronotopo (convivência de temporalidades no(s) tempo(s)/espaço) e a exotopia (articulação de espaços no processo de criação verbal), o insumo suficientemente aberto para dirimir a realidade heteronímica do autor. As análises exotópicas e cronotópicas de excertos poéticos de Pessoa (ortônimo) e de seus heterônimos (Reis, Caeiro e Campos) apontam uma subjetividade povoada e dialógica. A poética pessoana sugere presenças extralocalizadas e temporalidades em convivência no tempo presente do autor. Assomampersonas diversificadas artística e biograficamente, bem como múltiplas temporalidades (passado, presente e um projeto de futuro do sujeito e da nação).

\footnotetext{
${ }^{1}$ Professor da Rede Estadual de Mato Grosso (Seduc-MT). Mestre em Estudos de Cultura Contemporânea pela Universidade Federal de Mato Grosso (ECCO-UFMT). Santo Antônio de Leverger-MT; Brasil, moisescarmorim@hotmail.com

${ }^{2}$ Mestre em Estudos de Linguagem pela Universidade Federal de Mato Grosso(PPGEL-UFMT); Campinas-SP; Brasil, diegopsousa@ hotmail.com
} 
Palavras-chave: Heterônimos; Tempo e espaço; Exotopia; Cronotopo

Abstract: The phenomenon of heteronomy found its origin and more fruitful source polyphonic writing of the poet Fernando Pessoa. In his work, testify is a complex and dynamic space/time of literarycreation, with a confluence of multiple temporalities, facets and personalities in a dialogical artistic and biographical space. In this reflection identified in concepts of Bakhtin's, cronotopo (temporality of living in (s) time (s) / space) and exotopy (spaces of articulation in verbal creation process), the open enough input to settle the heteronímica reality of the author. The exotópicas analysis and chronotopic poetic excerpts Person (orthonymous) and its heteronyms (Reis, Caeiro and Campos) indicate a populated and dialogical subjectivity. The Pessoan poetic suggests extralocalized presence and temporality in living the author of this time. Loom diverse personas artistic and biographically, as well as multiple (temporality) (past, present and future design of the subject and the nation).

Keywords: Heteronyms; Time and space; Exotopy; Chronotope

\section{Introdução}

Para criar, destruí-me; tanto me exteriorizei dentro de mim, que dentro de mim não existo senão exteriormente. Sou a cena viva onde passam vários atores representando várias peças.

Fernando Pessoa

Da memória do mundo sou uma lembrança jamais apagada. No grande tempo dialógico permaneço como uma faísca que nunca se extingue. Não há ninguém fora dele, porque a vida em sua natureza dialógica, e em sua (in)completude, reconhece um início e um fim-traço 
intermitente sem limite, de efêmera e contínua duração. Nesse sentido, transcendendo a individualidade, a vida (e o sujeito vivente) abrange tanto o mundo social quanto o mundo da cultura, fenômeno refletido pelo pensador russo Mikhail Bakhtin, bem como pelo Círculo, em diversos momentos de suas obras. A palavra diálogo é central na concepção de linguagem dos teóricos supracitados.

Por meio da dialogia, paradoxos como o efêmero e o contínuo - a memória e o esquecimento - podem ser coadunados. Em verdade, cada enunciado concreto, a unidade primeira e última da linguagem, é um elo (passageiro e perene) na cadeia ininterrupta do fenômeno verbal. Outros conceitos bakhtinianos, no entanto, não menos dialógicos, conduzirão nossa reflexão acerca da obra de Fernando Pessoa (1888-1935), a saber: Cronotopo e Exotopia.

Na confluência da abertura e ao mesmo tempo modéstia que a consciência dialógica da artee davida estabelecem, esta pesquisa pretende, a partir dos conceitos de cronotopo e exotopia, refletir o fenômeno da heteronímia na vida e obra de F. Pessoa. Em seu ortônimo e heterônimos vê-se uma complexa, e ainda não amplamente visitada, relação das fronteiras entre tempo e espaço - criação e autoria - realidade e ficção que, acreditamos, pode ser relida a partir da cronotopia (convivência de temporalidades no tempo/espaço) e exotopia (articulação de espaços no processo de criação verbal).

A fim de dar insumo e estabelecer uma plataforma para a análise da relação entre tempo(s) e espaço na obra pessoana procederemos, inicialmente, com a apresentação dos conceitos e do fenômeno da heteronímiae, em seguida, análises das relações cronotópicas e exotópicas de excertos poéticos de Fernando Pessoa (ele mesmo) e de alguns de seus reconhecidos heterônimos (Reis, Caeiro e Campos). As análises apontam uma subjetividade povoada e dialógica do vate português. Em suas expressões artísticas assistem-se presenças extralocalizadas e temporalidades em convivência no tempo presente do autor. Evidenciam- 
se, assim, personas diversificadas artística e biograficamente em Pessoa, bem como múltiplas temporalidades (o passado, o presente e o projeto de futuro de um português e da nação portuguesa).

\section{Pessoa entre o Crono e o Topo}

ParaBakhtin emcada troca dialógica ocorre uma visão privilegiada do cenário e horizonte alheio, o que é denominado excedente da visão estética. Efetivamente ao se olharem "[...] dois diferentes mundos se refletem na pupila de seus olhos" (BAKHTIN, 2010, p. 21), o sujeito vê privilegiadamente o horizonte alheio e por este é privilegiadamente visto. Tais polos jamais se substituem, no entanto, se influenciam e interconstituem, de sorte que a insubstitutibilidade do lugar que cada sujeito ocupa promove um olhar povoado pelo mundo do outrem, mas, semelhantemente singularizado e único.

O processo de significação da existência é fruto de uma constante (re)articulação da realidade sob a égide do encontro entre dois mundos, o próprio e o alheio. Assim, é possível desvelar da teoria dialógica uma Filosofia da reciprocidade, uma Linguística do encontro, uma Pedagogia da alteridade, uma Didática do outro. Se o conceito de exotopia abriga a articulação de dois lugares: o lugar próprio e o lugar alheio; é possível notar, por especificidades literárias e bibliográficas, uma essência exotópica nas práticas artísticas e existenciais do poeta lusitano.

Amorim (2010) figura o conceito de exotopia a partir do exemplo do retrato, que na criação estética apresenta as distinções e "[...] a tensão entre dois olhares [...] em pintura [...] do olhar do retratado e do olhar do retratista ou artista." (AMORIM, 2010, p. 96). Ao retratar, "O trabalho deste último consiste em dois movimentos: primeiro, o de tentar captar o olhar do outro [...]; segundo, de retornar ao seu lugar [...] para sintetizar ou totalizar o que vê, de acordo com seus valores [...]" (idem, ibidem). Enquanto 
o retratado vive seu constitutivo inacabamento - pois não pode ter uma visão holística de si mesmo - o retratista, a partir de seus referenciais, pondera o mundo alheio, tenta mirar com a íris do outro, mas por não ser o outro e vê-lo a partir de sua exterioridade limita-o com o cenário que sob sua perspectiva circunda o retratado.

Em Pessoa, e em seus heterônimos, vemos uma aplicação semelhante e até uma superação deste fenômeno. Sua obra apresenta uma subjetividade povoada emqueapresençadarelaçãoexotópicanãoéelemento, mas sim condição. A relação do Poeta com o espaço é de uma permanente dinâmica, sua subjetividade, tanto na arte como na vida, é enraizada no inacabamento e na extralocalização. Há, todavia, uma dimensão da obra do poeta lisboeta que com o conceito de cronotopia torna-se possível refletir: a temporalidade. A questão do tempo permeia e inquieta Bakhtin em toda sua obra. As reflexões sobre o tempo constituem papel fulcral em conceitos como o de dialogia, tema e significação ou mesmo o de gêneros discursivos; além de ser decisivo em estudos literários como os realizados sobre as obras de Goethe e Dostoiévski. Para Bakhtin, aliás, a plenitude de uma obra literária revela-se apenas no grande tempo (BAKHTIN, 2010).

É, todavia, a luneta bakhtiniana da Cronotopia a eleita como instrumento para uma visão dialógica da obra de Pessoa. Em significativo estudo sobre o tempo nas produções goetheanas, Bakhtin, assim a define: "A capacidade de ver o tempo, de ler o tempo no todo espacial do mundo [...] de perceber o preenchimento do espaço não como fundo imóvel (2010, p. 225). Uma vez que "Tudo [...] Leva em si a marca do tempo [...] e nele ganha sua forma e sentido. Tudo nesse mundo é tempoespaço, cronótopo autêntico.” (2010, p. 245). A convivência e confluência das marcas do tempo no espaço, bem como do espaço no tempo é constituinte do labor artístico. No cronotopo artístico-literário, afirma Bakhtin, "[...] ocorre a fusão dos indícios espaciais e temporais num todo compreensivo e concreto. Aqui o tempo condensa-se, comprime-se, torna-se artisticamente visível; o próprio espaço intensifica-se, penetra no 
movimento do tempo, do enredo e da história." (BAKHTIN, 2002, p. 21). Assim, prossegue o russo "Os índices do tempo transparecem no espaço, e o espaço reveste-se de sentido e é metido como tempo." (idem, ibidem).

É preciso destacar aqui o assentimento de que a teorização sobre o fenômeno espaço-tempo realizada por Bakhtin e pelo Círculo fora dedicada ao fenômeno artístico-literário, emespecial, à prosa. No entanto, cremos que com uma devida e crítica leitura do dialogismo que nucleia o pensamento dos referidos autores, é possível identificar as realidades cronotópicas e exotópicas em outras manifestações semióticas e literárias. É o caso da poesia pessoana, aqui, relida bakhtinianamente. Vale salientar que essa rearticulação de elementos da teoria dialógica para estudo de diferentes objetos é empreendida com destreza por pesquisadores já estabelecidos no cenário dos estudos de linguagem (AMORIM, 2010; MACHADO, 2010). Ainda neste espírito dialógico, é necessária uma compreensão aberta e crítica da teoria do Círculo e de Bakhtin. Abertura e criticidade que motivem um pensar com e, não apenas, um pensar sobre a obra bakhtiniana. Eximir-se a este compromisso é ser arredio ou antitético à essência da dialogia, bem como aos riscos epistemológicos que a própria teoria estabelece.

\section{As Pessoas em Fernando Pessoa}

A poesia do século $\mathrm{XX}$ foi enriquecida com a obra de Fernando Pessoa. Elevou-se aos píncaros mais afastados, descortinando da consciência humana relações entre autor e obra, ficção e realidade, numa visão singular a respeito da arte, da estética, da sociedade, do indivíduo etc. Mestre da criação literária, Pessoa modificou o panorama da língua portuguesa ao conceber os heterônimos que são, conforme pode se depreender das reflexões do autor, seres com personalidades próprias (PESSOA, 1986). Tais seres ampliaram as letras universais, e foram se 
constituindo na imaginação do poeta até serem forjados. Desde a tenra infância, o heteronimismo esteve ligado às experiências do poeta: "[...] o meu primeiro conhecido inexistente - um certo Chevalier de Pas dos meus seis anos, por quem escrevia cartas dele a mim mesmo." (PESSOA, 1986, p. 199). Isso demonstra como Pessoa já possuíauma visão ampla da criação de seres imaginários, que figuravam e se relacionavam consigo. $\mathrm{O}$ mundo pessoano deve ser compreendido a partir da gênese da heteronímia, que aconteceu primeiramente na infância e se consolidou, enquanto criação, na vida adulta: "E assim arranjei, e propaguei, vários amigos e conhecidos que nunca existiram, mas que ainda hoje, a perto de trinta anos de distância, ouço, sinto, vejo.” (PESSOA, 1986, 199).

Povoar o mundo com personalidades singulares, dando-lhes um organismo ético-estético consolidou a obra pessoana como uma das mais abrangentes surgidas no modernismo. Pode-se dizer que isso ocorre pelo caráter exotópico da criação heteronímica, em que o poeta manifesta uma empatia e autoconstituição pelo alteritário, o qual está repleto de perplexidades, de utopias, de contradições, de sofrimentos, júbilos, emoções... Assim, ele perscruta o horizonte alheio, coloca-se no lugar do outro e, após a contemplação, retorna ao seu lugar único da existência, povoado de si, dos outros. "Ah poder ser tu, sendo eu" ( PESSOA, 2008, p. 139): vivenciar o universo humano - sendo reciprocamente Alberto Caeiro, Ricardo Reis, Álvaro de Campos. E, de modo singular, Fernando Pessoa: "Desde que me conheço como sendo [...] eu, me lembro de precisar mentalmente, em figura, [...] carácter e história, várias figuras irreais [...] tão visíveis e minhas como as coisas daquilo a que chamamos [...] a vida real. (PESSOA, 1986, p. 199). Confessa o drama em gente: "Esta tendência, que me vem desde que me lembro de ser um eu, temme acompanhado sempre, mudando um pouco o tipo de música com que me encanta, mas não alterando nunca a sua maneira de encantar." (Idem, Ibidem). É um sentimento recíproco com o alteritário, embora o escritor de romance ou de poesia não vivencie as dores alheias tal como as 
pessoas que sofreram. Em verdade, é impossível. Assim como os demais humanos, o escritor tem momentos felizes e infelizes, mas não é dessas categorias que o material artístico emerge como organismo vivo, palpável. Ele vem do excedente de visão estética, do esforço de compreensão do sentimento alheio, que significa, em termos gerais, colocar-se, a partir de suas referências identitárias, no lugar do outro. Portanto, o sentido da vida está no horizonte alheio, na relação eu-outro ali estabelecida.

A referida extralocalização, constitutiva da personalidade de Pessoa, transcende a mera reciprocidade ou fortuita empatia e é, na categorização bakhtiniana, como um modo de ser e de operar semiose. Como se, de fato, o sentido surgisse apenas em terreno dialógico, onde o significar é um substrato original e singular do grande tempo. Como o próprio Bakhtin afirma: "[...] chamo sentido a respostas." (2010, p. 381), uma vez que o que não responde não tem sentido e, seguidamente, inexiste. As respostas como elos na cadeia ininterrupta da linguagem estão intrinsecamente vinculadas, em sua natureza - forma e conteúdo, ao alteritário em sua maior e múltipla dimensão. Se a relação tempo-espaço é perenemente repensada pelos estudiosos do Círculo e por Bakhtin, na obra pessoana tal relação, como ver-se-á, é aplicada de maneira complexa e incomum. “[...] Essa exterioridade da alma do outro, como uma espécie de sutilíssima carne interior, é precisamente o que constitui a individualidade artística intuitiva e visível [...]" (BAKHTIN, 2010, p. 93). A dimensão do ser é, de acordo com a ótica do poeta, extensa e infinita; em termos bakhtinianos, ela é uma inteireza inacabada, pois cada pessoa tem uma singularidade que a distingue, colocando-a sob a própria responsabilidade. Embora sejam criações ficcionais, os heterônimos possuem também singularidades, consolidadas de modo filosófico e ético perante a vida. Cada um deles expõe uma visão ímpar do mundo e falam de um lugar único da existência construído pelo poeta. Por conseguinte, o ato ético-estético presente nos heterônimos é um amálgama do próprio autor, não se distanciando da sua assinatura. Para exemplificar isso, é importante que se perceba a criação 
de Pessoa (ele próprio) e a consciência exotópica do poeta, por exemplo, em Análise:

Tão abstracta é a ideia do teu ser

Que me vem de te olhar, que, ao entreter

Os meus olhos nos teus, perco-os de vista,

E nada fica ao meu olhar, edista

Teu corpo do meu ver tão longemente,

E a ideia do teu ser fica tão rente

Ao meu pensar olhar-te; e ao saber-me

Sabendo que tu és, que, só por ter-me

Consciente de ti, nem a mim sinto.

E assim, neste ignorar-me a ver-te, minto

À ilusão da sensação, e sonho,

Não te vendo, nem vendo, nem sabendo

Que te vejo, ou sequer que sou, risonho

Do interior crepúsculo tristonho

Em que me sonho o que me sinto sendo. (PESSOA, 2008, p. 103).

Nos poemas iniciais da obra pessoana já existe uma reciprocidade entre o eu e o outro: "Que me vem de te olhar, que, ao entreter/Os meus olhos nos teus, perco-os de vista". Como foi dito acima, a dimensão do ser, segundo a visãodo poeta,éextensae infinita;e, assim, inteira, mas inacabada: "Em que me sonho o que me sinto sendo". O eu se reconhece frente a frente, pois analisae perscruta as peculiaridades do outro. A verdadeira consciência de Pessoa é a compreensão do horizonte alheio. Para Bakhtin, "[...] o primeiro momento da atividade estética é a compenetração." (BAKHTIN, 2010, p. 23). O poeta reconhece que a vida e a arte fundamentam-se na compenetração do outro: nessa teia de relações entre artista eespectador. Vejamos a canção A Ceifeira (PESSOA, 2008, p. 139-140):

Ela canta, pobre ceifeira,

Julgando-se feliz talvez;

Canta, e ceifa, e a sua voz, cheia 
De alegre e anónima viuvez,

[...]

Ouvi-la alegra e entristece,

Na sua voz há o campo e a lida,

E canta como se tivesse

Mais razão pra cantar que a vida.

Ah, canta, canta sem razão!

O que em mim sente 'stá pensando.

Derrama no meu coração

A tua incerta voz ondeando!

Ah, poder ser tu, sendo eu!

Ter a tua alegre inconsciência,

[...]

Pesa tanto e a vida é tão breve!

Entrai por mim dentro! Tornai

Minha alma a vossa sombra leve!

Depois, levando-me, passai!

A enternecedora voz da mulher que canta enquanto trabalha tem uma suavidade, segundo o sujeito lírico: "Canta, e ceifa, e a sua voz, cheia/ De alegre e anónima viuvez"; a canção é sentida pelo sujeito lírico, pois na voz da mulher há o campo e a lida. Ao reconhecer a mulher cantando o sujeito lírico reconhece também os sentimentos do cantar: "E canta como se tivesse/Mais razões p'ra cantar que a vida". O paradoxo entre consciência (pesada e triste) e inconsciência (satisfeita e alegre) exprimem, nesta articulação, uma incompletude e insatisfação existencial pertencentes a uma identidade vária e movediça que em muito antecipa as crises do sujeito líquido pós-moderno. (BAUMAN, 2003). Em Pessoa vemos a convivência contraditória e inescapável entre matéria e tempo, sujeito e transcorrer da realidade.

A criação pessoana tem um caráter exotópico, principalmente a criação heteronímica que une os laços da percepção eu-outro. Mas também 
há uma atividade ética-estética de responsabilidade, pois cada heterônimo desenvolve uma obra que compreende uma vida social ampla. Assim cada faceta de Pessoa, ortônimo e heterônimos, revelam um relacionamento crítico-responsivo de determinada subjetividade com seu tempo e espaço. A própria literatura, e os demais constructos e legados socioculturais, sob essa perspectiva, seriam produtos responsivos do tempo histórico. A relação tempo e espaço na constituição dos heterônimos indicam um ortônimo cônscio do caráter movente do processo artístico, emremissão à dinamicidade da própria vida, da agenda permanentemente inacabada que é o autor e sua obra.

\section{Entre espaços e tempos: Reis, Caeiro e Campos}

O percurso realizado acima demonstrou a realidade diversa da personalidade literária de Fernando Pessoa ortônimo. Percebe-se uma multidimensionalidade no autor, traduzida na criação de mais de 127 heterônimos (CAVALCANTI FILHO, 2011), dos quais destacaremos a relação cronoexotópica dos 3 principais: Reis, Caeiro e Campos.

\section{Ricardo Reis}

A arte suscita uma plena vivência no tempo e pode conciliar aspirações humanas, tornando o instante derradeiro menos doloroso. Para a filosofia epicurista, ela não concebe nenhuma esperança futura, mas eleva a vida ao patamar de felicidade a quem compreende os ensinamentos da própria natureza, que nada deixa enunca regressa. Tal ensinamento remete ao jargão latino muito conhecido: carpe diem. Assim, sob esse prisma, o futuro é uma ilusão. O passado nunca regressa para cessar a frustração do ser. Resta ao homem viver o momento presente, sabendo que ao pó será reduzido. Essa filosofia clássica é substância dos poemas de Ricardo 
Reis, que, segundo Pessoa, “[...] nasceu em 1887 (não me lembro do dia e mês [...]), no Porto, é médico e está presentemente no Brasil, "[...] pus emRicardo Reis toda a minha disciplina mental, vestida da música que lhe é própria [...]" (PESSOA, 1986, p. 19). Reis compreende que a sabedoria está ligada com a maneira que se observa o mundo. É o que figura em Vem sentar-te comigo, Lídia, à beira do rio:

Vem sentar-te comigo, Lídia, à beira do rio.

Sossegadamente fitemos o seu curso e aprendamos

Que a vida passa, e não estamos de mãos enlaçadas.

(Enlacemos as mãos).

Depois pensemos, crianças adultas, que a vida

Passa e não fica, nada deixa e nunca regressa,

Vai para um mar muito longe, para ao pé do Fado,

Mais longe que os deuses [...]

Colhamos flores, pega tu nelas e deixa-as

No colo, e que o seu perfume suavize o momento -

Este momento em que sossegadamente não cremos em nada,

Pagãos inocentes da decadência [...] (PESSOA, 2008, p. 269-270).

Na poética clássica, o poeta glorifica o tempo presente e alude a consciência para a questão da brevidade da vida. Ricardo Reis, seguindo os ensinamentos de Horácio, molda o espaço e o tempo em coexistência profunda com a vida dos homens: o espaço natural, com rios a correr e flores no chão, produz o caráter de satisfação com o momento em que se vive: "Vem sentar-te comigo, Lídia, à beira do rio./Sossegadamente fitemos o seu curso e aprendamos/ que a vida passa [...]". Para o poeta, a plenitude da existência reside em aproveitar o momento, que passa e não regressa jamais, como os rios que correm para o mar aludindo à metáfora de Heráclito sobre a permanente dinâmica da vida. Nas odes, o espaçotempo existe como crença dos amantes para a entrega total do amor e da vida: "Colhamos flores, pega tu nelas e deixa-as/No colo, e que o seu perfume suavize o momento [...]". Toda a entrega dos amantes torna-se 
verdadeira porque é uma entrega no tempo presente e num espaço único da natureza, vivendo contente o espetáculo do mundo. Nesse momento presente, se consolidam o passado e o futuro, já que se estendem na emoção de aproveitar o dia: “[...] A concepção de tempo traz consigo uma concepção de homem e [...] cada nova temporalidade [...] um novo homem. Parte, portanto, do tempo para identificar o ponto em que este se articula com o espaço e forma com ele uma unidade." (AMORIM, 2010, p. 102-103).

Deste modo, o ser humano passa a valorizar cada fagulha de vida sob a terra. Reis é o poeta que reflete a substancialidade verdadeira do tempo presente, destituindo as ilusões corriqueiras acerca do porvir, reconhecendo avitalidade do momento, pois, segundo ele:

Sábio é o que se contenta com o espetáculo do mundo,

$\mathrm{E}$ ao beber nem recorda

Que já bebeu na vida,

Para quem tudo é novo

E imarcescível sempre.

Coroem-no pâmpanos, ou heras, ou rosas volúteis,

Ele sabe que a vida

Passa por ele e tanto

Corta à flor como a ele

De Átropos a tesoura.

[...]

E ele espera, contente quase e bebedor tranqüilo,

E apenas desejando Num desejo mal tido

Que a abominável onda

O não molhe tão cedo. (PESSOA, 2008, p. 271).

O conceito de carpe diem traduz o sentimento do poeta, o qual reconhece que "[...] tudo é novo/E imarcescível sempre". Por isso, o presente deve ser aproveitado, como tempo uno, onde coexistem o passado e o futuro, onde não há frustração do não vivido ou saudosas lembranças já ressequidas. Em Reis a totalidade do tempo está no 
presente, solidificando uma visão categórica de tempo no momento em que se vive: "Ele sabe que a vida/Passa por ele e tanto/Corta à flor como a ele/De Átropos a tesoura". Além dessa totalidade de vivência no presente, o poeta também reflete a morte como acabamento do prazer vivido. O sujeito, enquanto fica satisfeito com o sabor do vinho, que apaga o gosto às horas, "[...] espera contente quase e bebedor tranqüilo". Nenhum dos heterônimos promove uma reflexão tão compensatória do momento; aliás, essa valorização do agora tem um aspecto de consciência importante. A magnitude do tempo na poesia de Ricardo Reis evidencia o caráter singular da visão pessoana acerca da existência, que precisa ser plenamente consumida. O poeta neoclássico reconhece cada momento como fundamental que precisa ser vivido: sua filosofia redimensiona as experiências do aqui/agora. É possível, dessa forma, identificar na estética de Reis uma figuração cronotópica que desavisada do passado e do futuro concebe o momento como o maestro de toda a temporalidade.

\section{Alberto Caeiro}

Importante nome da criação pessoana é o poeta Alberto Caeiro. O seu nascimento é relatado da seguinte forma: "Foi o dia triunfal da minha vida, e nunca poderei ter outro assim [...]. E o que se seguiu foi o aparecimento de alguém em mim, a quem dei desde logo o nome de Alberto Caeiro"(PESSOA, 1986,p. 199).É o poetafilósofo, que perscruta o mundo sem a filosofia, já que o pensamento adoece os olhos. Mestre de Pessoa, Reis e Campos, sua obra promove uma indagação das experiências que envolvem o ser humano na existência. O mestre procura compreender a natureza através da sensação, através da filosofia do olhar, como Bakhtin (2010) reflete na obra Viagens à Itália de Goethe. Contudo, diferentemente de Goethe, Caeiro utiliza o olhar e outras sensações sem a interferência 
do pensamento. "Pensar é estar doente dos olhos" (PESSOA, 2008, p. 199): assim é preciso compreender que a filosofia desse heterônimo tem uma abrangência contra o racionalismo. Na aldeia onde o poeta reside, as pedras, o vento, as flores, o luar, enfim, todo elemento natural, torna-se substância de sua contemplação. Pode-se dizer que Caeiro reconhece a sua aldeia como parte total do mundo. Há diversas semelhanças entre o heterônimo de Fernando Pessoa com o poeta alemão: "[...] Goethe queria saber e sabia sempre ver com os olhos. Para ele o invisível não existia. [...] seu olhar não queria (e não podia) ver nada pronto e imóvel." (BAKHTIN, 2010, p. 229). Justamente por isso, "Seu olhar não reconhecia a simples contigüidade espacial, asimplescoexistênciadosobjetose fenômenos. Por trás de toda a diversidade estática ele enxergava a diversidade de tempos." (idem, ibidem).

Assim como Goethe, Caeiro tem fascinação pelo visível; mas esta fascinação é despida da emoção e do pensamento. Desta maneira, pode-se afirmar que passado, presente e futuro coexistem de maneira singular na sua obra, haja vista que o espaço, onde passam as estações, marca o ciclo da existência. A cronotopia é profícua para a compreensão da filosofia do mestre, que reconhece sua vivência particular em relação à vivência dos outros seres humanos: "Da minha aldeia vejo quanto da terra se pode ver no universo" (PESSOA, 2008, p. 205). Este modo de perceber/ estar na aldeia, reconhecida como pequeno mundo do poeta que está no grande tempo, solidifica claramente a presença do homem no espaço, consequentemente no tempo. Pode se dizer que em Goethe e Caeiro há uma "[...] capacidade de ver o tempo, de lero tempo no todo espacial do mundo $[. .$.$] de perceber o preenchimento do espaço não como um fundo$ imóvel e um dado acabado [...] mas como um todo em formação, como acontecimento [...]" (BAKHTIN, 2010, p. 225). Tal exercício, segundo o teórico da dialogia, é "[...] a capacidade de ler os indícios do curso do tempo em tudo, começando pela natureza e terminando pelas regras e idéias humanas [...]" (BAKHTIN, 2010, p. 225). Uma vez que “[...] os visíveis 
indícios complexos do tempo histórico, na verdadeira acepção do sentido, são vestígios visíveis da criação do homem, vestígios de suas mãose de sua inteligência [...]" (idem, ibidem).

A ideia de espaço coaduna com uma filosofia do olhar, sendo fulcral para uma poética das sensações, com plena visão da natureza:

[...]

Nas cidades a vida é mais pequena

Que aqui na minha casa no cimo deste outeiro. $\mathrm{Na}$ cidade as grandes casas fecham a vista à chave, Escondem o horizonte, empurram o nosso olhar [para longe de todo o céu,

Tornam-nos pequenos porque nos tiram

[o que os nossos olhos nos podem dar,

E tornam-nos pobres porque a nossa única riqueza é ver. (PESSOA, 2008, p. 205).

Estar no espaço é estar também no tempo, esta simbiose implica numa convivência inter-espaço-temporal, já que o passado está repleto no presente, e este ancorado no futuro. Assim como Goethe que, segundo Bakhtin, encontrava as nuances do tempo nos elementos mais simples da natureza, nas rugas da face do habitante, na memória dos rios que deslizam incessantemente, Alberto Caeiro perscruta cada ser com uma contemplação absoluta, moldada pela legitimidade do olhar. Essa filosofia é comum em ambos: crotonopo vivenciado pelas sensações. Mas, no mestre de Fernando Pessoa, a sensação emerge para colher da realidade uma existência valorada: porque a nossa única riqueza éver. Como categoria artística, a obra O guardador de rebanhos demonstra uma vivência no espaço-tempo (aldeiapresente/passado/futuro) em absoluta convergência:

Ao entardecer, debruçado pela janela,

E sabendo de soslaio que há campos em frente,

Leio até me arderem os olhos

O livro de Cesário Verde. 
Que pena que tenho dele! Ele era um camponês

Que andava preso em liberdade pela cidade.

Mas o modo como olhava para as casas,

E o modo como reparava nas ruas,

E a maneira como dava pelas cousas,

É o de quem olha paraárvores,

E de quem desce os olhos pela estrada por onde vai andando

E anda a reparar nas flores que há pelos campos...

Por isso ele tinha aquela grande tristeza

Que ele nunca disse bem que tinha,

Mas andava na cidade como quem anda no campo

E triste como esmagar flores em livros

E pôr plantas em jarros... (PESSOA, 2008, p. 199-200).

A vivência no tempo indica uma contínua duração: "Aoentardecer, debruçado pela janela/E sabendo de soslaio que há campos em frente./ Leio até me arderem os olhos/O livro de Cesário Verde". O verbete temporal não explícita um tempo específico, sendo assim indefinido e valorando uma ideia de todos os entardeceres, tanto do passado, quanto do presente e do futuro. No tempo está o espaço (campos em frente), enriquecido pela filosofia do olhar - (Leio até me arderem os olhos/O livro de Cesário Verde) que permite a reflexão de que a leitura é uma atividade de saber olhar, saber contemplar a realidade. Através da leitura, Caeiro compreendeCesário Verde (poetaque "era um camponês, mas vivia preso em liberdade pela cidade"), ou melhor, através da cultura do olhar, que o seu mestre Cesário também demonstrava no espaço citadino ao reparar nas casas como se elas fossem árvores: "E o modo como reparava nas ruas/E a maneira como dava pelas cousas/É o de quem olha para árvores". Caeiro tinha o poeta português da geração realista como mestre. A semelhança entre ambos são reconhecíveis, pois de Cesário Verde o heterônimo herdou uma ótica humilde e filosófica sobre o espaço rural. 
Assim, o cronotopo em Caeiro desdobra uma filosofia da sensação, que se assemelha a cultura do olhar em Goethe. Acerca deste Bakhtin salienta “[...] a importância [...] da visibilidade [...] Todos os demais sentimentos exteriores, a vivência interior, as reflexões e conceitos abstratos se uniram em torno do olho que vê como seu centro, como a primeira e última instância." (BAKHTIN, 2010, p. 227). E o filósofo russo continua: "Tudo o que é essencial pode e deve ser visível; tudo o que é invisível é secundário.É amplamente conhecida a grande importância que Goethe dava à cultura do olhar e com que profundidade e amplitude ele compreendia essa cultura." (idem, ibidem).

Otempo-espaço, portanto, éumacategoria visível, quese relaciona com uma percepção acerca das coisas. Em Alberto Caeiro a percepção dialoga com o mundo, que passa a ser compreendida por uma atitude não racionalista. No tempo, os elementos da natureza se revelam de maneira absoluta, ao sabor das estações, no seu estado natural de vida e de morte. Com isso, pode-se dizer que o mestre, assim como Goethe, é um homemconstrutor e deseja “[...] veros laços necessários desse passado como presente vivo [...], que em certo sentido antecipa o futuro" (BAKHTIN, 2010, p. 235). A sua poesia apresenta uma riqueza do olhar, uma percepção do tempo - passado, presente, futuro - que formam a realidade e possibilitam uma abordagem dos tempos no espaço.

\section{Álvaro de Campos}

Mas há também uma voz que vislumbra, de maneira inquieta, o futuro, vendo parcialmente nos acontecimentos do passado, a marcha para um mundo novo. Essa voz é a do heterônimo Álvaro de Campos, conhecido como o poeta futurista, que canta a máquina, o automóvel, num frenético turbilhão de nervos: "À dolorosa luz das grandes lâmpadas elétricas da fábrica/Tenho febre e escrevo" (PESSOA, 2008, p. 287). 
Essa voz arrebata a calmaria do mundo antigo, compreendendo questões prementes da modernidade, como o efêmero, a velocidade, os avanços da indústria e da tecnologia etc. Pode-se dizer que é a voz da multidão alienada pela máquina. Em Campos, o tempo soa de modo categórico, pois a sua escrita sabe que para haver futuro é necessário haver passado e presente, pois, segundo ele, "[...] há Platão e Virgílio dentro das máquinas e das luzes elétricas/Só porque houve outrora e foram humanos Virgílio e Platão" (PESSOA, 2008, p. 288). Antes, porém, o poeta diz, de modo grandiloquente: "[...] porque o presente é todo o passado e todo futuro" (Idem, Ibidem). E, de fato, para o poeta da Ode Triunfal, passado-presentefuturo se interseccionam, mas não é para louvar o momento, como fazia Reis, nem para perscrutar, com a filosofia do olhar, os elementos da natureza no tempo, como ensina Caeiro; Campos aceita a cidade, está nela imerso e alienado, indagando uma nova natureza para o mundo moderno. Essa natureza, regida pela matéria plena da técnica, onde a natureza criada por Deus será substituída pela artificialidade da máquina criada pelo homem. Basta refletir sobre as metáforas que o engenheiro usa na sua Ode Triunfal para cantar a modernidade: "Rasgar-me todo, abrir-me completamente, tornar-me passento/A todos os perfumes de óleos e calores e carvões/Desta flora estupenda, negra, artificial e insaciável!" (PESSOA, 2008, p. 289).

Assim, realidade e homem se alienam, desarticulam-se da natureza e articulam-se à substância da crescente industrialização do mundo, no início do século XX. Se em Reis vê-se o culto relacional com o tempo presente e em Caeiro o tempo lido na natureza concreta, em Campos a inserção da lógica tecnicista, a derrocada das metanarrativas e o êxito do empreendimento industrial imbricam-se num sujeito vário, líquido, descentrado e insatisfeito em suas (in)certezas. Goethe, transcrito por Bakhtin, afirma que aquele "[...] que não possuiuma verdadeira existência interior não possui vida [...]" (2010, p. 241). Em Pessoa nota-se uma interioridade abundante. Tal riqueza transcende uma subjetividade 
ensimesmada e egóica, e, essencialmente, dialógica, babélica e polifônica. Campos, engenheiro-futurista, almeja que o mundo se transforme sempre no porvir e na mudança, para lhe arrancar da monotonia dos lugares calmos. A sua revolta é contra a estagnação do homem no tempo. Dessa maneira, percebe-se que se avoluma o caos interior do indivíduo, pois no espaço e no tempo ocorre a alienação do homem, que se transmuta em máquina, coisa hostil. A máquina substitui a humanidade. E o mundo se torna uma selva mecânica.

Outra postura do engenheiro é a angústia frente às ações da vida. $\mathrm{O}$ tédio em relação à vida promove a apatia do homem moderno, a prorrogação de seus planos e a desistência frente aos sonhos. O tempo presente nada significa para quem sofre a instabilidade célere da industrialização. Toda a sua vida é adiada: a atitude de Campos mostra-se, de certo modo, melancólica e desesperadora, pois o poeta implode com raiva para o mundo. Ele é espectadordasuaprópria vida, jamais protagonista.Paraquemsofre, o porvir torna-se esperança, mas também sensação de tristeza. A industrialização, o caos cotidiano, a velocidade formaram um sujeito descentralizado, vazio de expectativas, de objetivos concretos. Campos possui uma forte revoltosa voz, mas na verdade sua voz carrega uma fragilidade que retrata o sujeito moderno. Isso fica mais observável em Adiamento:

Depois de amanhã, sim, só depois de amanhã...

Levarei amanhã a pensar em depois de amanhã,

E assim será possível; mas hoje não...

Não, hoje nada; hoje não posso [...]

Tenho já o plano traçado; mas não, hoje não traço planos...

Amanhã é o dia dos planos.

Amanhã sentar-me-ei à secretária para conquistar o mundo;

Mas só conquistarei o mundo depois de amanhã...

Tenho vontade de chorar,

Tenho vontade de chorar muito de repente, de dentro...

Não, não queiram saber mais nada, é segredo, não digo.

Só depois de amanhã [...] PESSOA, 2008, p. 384-385 ). 
Adualidade e descentramentotambém podem ser vistosemAfinal, a melhor maneira de viajar é sentir (PESSOA, 1993, p. 34), uma pertinente definição de sua condição heteronímica: "[..] Quanto mais eu sinta, quanto mais eu sinta como várias pessoas,/Quanto mais personalidades eu tiver, Quanto mais intensamente, estridentemente as tiver, Quanto mais simultaneamente sentir com todas elas [...]" e o poeta prossegue "Quanto mais unificadamente diverso, dispersadamente atento,/ Estiver, sentir, viver, for,/Mais possuirei a existência total do universo,/Mais completo serei pelo espaço inteiro fora. [...]" (idem, ibidem). Os versos acima não apenas descrevem a personalidade poética de Álvaro de Campos, como também indicam a exotopia presente na vida e obra de Fernando Pessoa. Esse drama em gente éo substrato de uma subjetividade povoada. Espécie de prenúncio da própria crise identitária vivenciada pela humanidade no século XX. Tal crise provoca a angústia moderna, que se estagna em relação à existência.

Campos é o engenheiro revoltado, como dizem os biógrafos e os críticos literários, mas, sobretudo, e de modo mais profundo, é um homem apático e doente, que sofre as crises oriundas do tempo moderno. Em verdade, sua personalidade revoltosa esconde um homem frágil, inadaptado, semelhante ao perfil poético de António Nobre. A diferença entre ambos é que o poeta do Só não proclamou com ânsia as crises do século insdustrial. O que prevalece em Álvaro de Campos, num primeiro momento, é a figura da força. Mas tal figura, em uma espécie de esquizofrenia cronoexotópica, logo se esvai e aparece a do homem frágil e doente, que está acorrentado à selva mecânica. O tempo célere, vivo e audaz, na desolação do homem moderno, possui uma dinamicidade inerente; não há glorificação da vida nesse tempo. Em sua relação exotópica, Campos deseja que as coisas tenham a morte natural ou a morte antecipada: sua voz apaga as ilusões românticas. Em sua cronotopia, por sua vez, o seu tempo é o tempo da revolução da máquina: sua natureza é a estupenda gestação do mundo industrializado. 


\section{Considerações Finais}

Segundo Barthes (2009)é papel da literaturaépropor indagações a um mundo acostumado às explicações ideológicas. Talvez assim a poesia se configure na história com uma função relevante, que determine o valor do homem no espaço e no tempo. Valores que inspirem a consciência a regozijar-se na poesia, sendo parte da história, forjada para romper os laços que aprisionam a vida. E Pessoa teve o compromisso com a integralidade da existência, lida aqui a partir dos conceitos: de exotopia e cronotopia, pois produziu uma obra diversificada e representativa de variadas facetas humanas e sociais como pode ser visto em seu ortônimo e heterônimos. Vê-se aqui a pertinência do conceito de cronotopo para desvelar a heteronímia pessoana, pois num único (mas múltiplo) espaço ocupado pelo sujeito, confluem-se múltiplas temporalidades. Pela porta dos cronotopos identificamos estratos sociais, subjetividades e tempos históricos. O espaço, como vemos em Goethe (BAKHTIN, 2010), não é inerte, tampouco vazio, mas congrega e carrega consigo sinais, testemunhas e artefatos da vida humana estendida no grande e dialógico tempo da história.

Com sua dialogia, Bakhtin humaniza o tempo e a história (ARÁN, 2006) e Fernando Pessoa, em seu labor artístico, subverte e cronotopiza o tempo-espaço, vida e arte. Em sua atividade criadora, o poeta português forja novas dimensões no processo de escrita. Sua personalidade movente se expressa em moventes personalidades. De modo que em sua obra poética, espaço-tempo se confundem e temporalidades várias coexistem. A crise heteronímica alegoriza a própria crise identitária que, construída no decorrer do século XX, viria a afligir os sujeitos do mundo contemporâneo. Nesse sentido Pessoa, e outros como Sá-Carneiro, como faróis da raça anteviram processos da subjetividade volátil do sujeito pósmoderno. Ao levar em conta que "A vida é dialógica por natureza" e que "Viver significa participar do diálogo" (BAKHTIN, 2010, p. 348). 
Pessoa não apenas participou como adentrou o grande tempo dialógico e com ele construiu sua episteme artístico-criadora expressando, assim, múltiplas facetas sociais, estéticas e variadas temporalidades.

\section{Referências}

AMORIM, M. Cronotopo e exotopia. In: BRAIT, Beth (Org.) Bakhtin: Outros Conceitos-chave. São Paulo-SP: Contexto, 2010, p. 95-114.

ARÁN, Pampa Olga (dir. y coord.). Nuevo diccionário de la teoria de Mijaíl Bajtín. Córdoba: Ferreyra Editor, 2006.

BAKHTIN, M. Estética da Criação Verbal. São Paulo: wmfMartins Fontes, 2010.

BAKHTIN, M.; Questões de Literatura e de Estética-A Teoria do Romance. São Paulo: Unesp/Hucitec, (1975) 2002.

BARTHES, R. Crítica e verdade/Roland Barthes. [Trad. Leyla PerroneMoisés]. São Paulo-SP: Perspectiva, 2009.

BAUMAN, Z. Modernidade Líquida. Rio de Janeiro: Zahar, 2003.

CAVALCANTI FILHO, J. Fernando Pessoa: uma quase autobiografia. Rio de Janeiro-RJ: Record, 2011.

MACHADO, I. A questão espaço-temporal em Bakhtin: Cronotopo e Exotopia. In. DE PAULA; STAFUZZA (orgs.). Campinas-SP: Mercado das Letras, 2010, p. 203-234.

PESSOA, P. Escritos Íntimos, Cartas e Páginas Autobiográficas: Fernando Pessoa. Lisboa: Publ. Europa-América, 1986. 
PESSOA, F. Livro de Versos. Lisboa: Estampa, 1993.

PESSOA, F. O eu profundo e os outros eus/Fernando Pessoa. Rio de janeiro: Nova Fronteira/PocketOuro Agir, 2008. 
Revista Leitura V. 2 n 57 - jul/dez 2016 - Poesia e História 